\title{
A new case of communal egg-laying by iguanas and American crocodiles (Crocodylus acutus Cuvier, 1807) from a Caribbean atoll of Mexico
}

\author{
Pierre Charruau ${ }^{1, *}\left(\mathbb{D}\right.$, Axel Rissac ${ }^{2}$, and David A. Macías Diaz ${ }^{3}$ \\ ${ }^{1}$ Centro del Cambio Global y la Sustentabilidad A.C., C.P. 86080 Villahermosa, Tabasco, México. \\ ${ }^{2}$ Université de La Réunion, La Réunion, France. \\ ${ }^{3}$ Comisión Nacional de Áreas Naturales Protegidas, Reserva de la Biosfera Banco Chinchorro, Chetumal, Quintana Roo, México. \\ "Corresponding author (charruau_pierre@yahoo.fr)
}

Edited by: Robert Henderson. Date of publication: 16 December 2021

Citation: Charruau P, Rissac A, Massias Diaz DA (2021) A new case of communal egg-laying by iguanas and American crocodiles (Crocodylus acutus Cuvier, 1807) from a Caribbean atoll of Mexico. Caribbean Herpetology, 80, 1-5.

DOI: https://doi.org/10.31611/ch.80

Communal egg-laying in oviparous animals occurs when two or more conspecific females deposit their eggs in the same nest cavity (Espinoza \& Lobo 1996). Although this behavior appears to be more widespread among reptiles than initially thought (Doody et al. 2009), interspecific communal egg-laying, which involves different reptile species, has been reported less frequently in the literature (Alfonso et al. 2012, Escobedo-Galván et al. 2019). Recently, Escobedo-Galván et al. (2019) published a review of reptile species that have been observed depositing their eggs in crocodile nests. In addition, Platt et al. (2021) provide more information on some reptile species nesting in Crocodylus moreletii and hybrid (C. moreletii x C. acutus) nests in Belize. These studies revealed that interspecific communal egg-laying has been documented for eight (33.3\%) of the 24 crocodilian species recognized by the IUCN crocodile specialist group (http://www.iucncsg.org/pages/Crocodilian-Species.html). Among these eight species, three are from the family Alligatoridae (Alligator mississippiensis, Caiman latirostris, and Melanosuchus niger) and five are from the family Crocodylidae (Crocodylus acutus, C. intermedius, C. moreletii, C. novaeguineae, and C. rhombifer) (Escobedo-Galván et al. 2019). There also exist cases of interspecific communal egg-laying in nests of $C$. acutus x C. moreletii hybrids in Belize (Platt et al. 2021). Twenty-five reptile species have been recorded to deposit their eggs in these crocodile nests: 15 turtles, six lizards, and four snakes (Escobedo-Galván et al. 2019, Platt et al. 2021). Here we report a new case of interspecific communal egg-laying between Crocodylus acutus and iguanas on Cayo Centro, Banco Chinchorro Atoll, Quintana Roo, Mexico.

Banco Chinchorro Atoll is a Biosphere Reserve located off the southeastern coast of the Mexican state of Quintana Roo, on the Yucatan Peninsula (see description in Charruau 2021). Cayo Centro is by far the largest cay of the atoll (541 ha) and is located in the center of the reef lagoon (Charruau 2021). Since 2006, we have been monitoring (annually) the reproduction of a recovering population of American crocodiles (Crocodylus acutus) present on this cay (Charruau et al. 2005, 2010, 2013, 2022, Charruau \& Hénaut 2012, Charruau 2012). On May 17, 2021, during our annual survey, we found a crocodile nest $\left(18.57^{\circ} \mathrm{N},-87.33^{\circ} \mathrm{W}\right)$ containing 16 iguana eggs beneath $17 \mathrm{C}$. acutus eggs (Fig. 1). The crocodile nest was a mound ( $140 \mathrm{~cm}$ wide $\times 150 \mathrm{~cm}$ long $\times 36 \mathrm{~cm}$ high) and the substrate consisted mainly of sand with some leaf litter and a black nylon rope (Fig. 2). Crocodile eggs $(n=17)$ had a mean length of $66.1 \pm 2.2 \mathrm{~mm}$ (range: $63.2-71.7 \mathrm{~mm}$ ), mean width of $42.3 \pm 0.7 \mathrm{~mm}$ (range: $41.2-43.7 \mathrm{~mm}$ ), and mean mass of $71.5 \pm 4.5 \mathrm{~g}$ (range: $66.3-84.1 \mathrm{~g}$ ). Iguana eggs $(n=15)$ had a mean width of $22.2 \pm 0.6 \mathrm{~mm}$ (range: $21-23$ $\mathrm{mm}$ ), mean length of $32.1 \pm 0.5 \mathrm{~mm}$ (range: $31-33 \mathrm{~mm}$ ), and mean mass of $9.0 \pm 0.6 \mathrm{~g}$ (range: 7.7-9.9 g). Unfortunately, it was not possible to determine the iguana species based on external egg characteristics. Two species of iguanids are present on the island, the green iguana (Iguana iguana) and the black iguana (Ctenosaura similis) (Charruau et al. 2015, 2020). The clutch and egg characteristics we obtained were within the range of measurements reported previously for these two species (Fitch \& Henderson 1978, van Marken Lichtenbelt \& Albers 1993, Alvarado et al. 1995, Muñoz et al. 2003, Campos \& Desbiez 2013, Avery et al. 2014). Iguana iguana is already known 


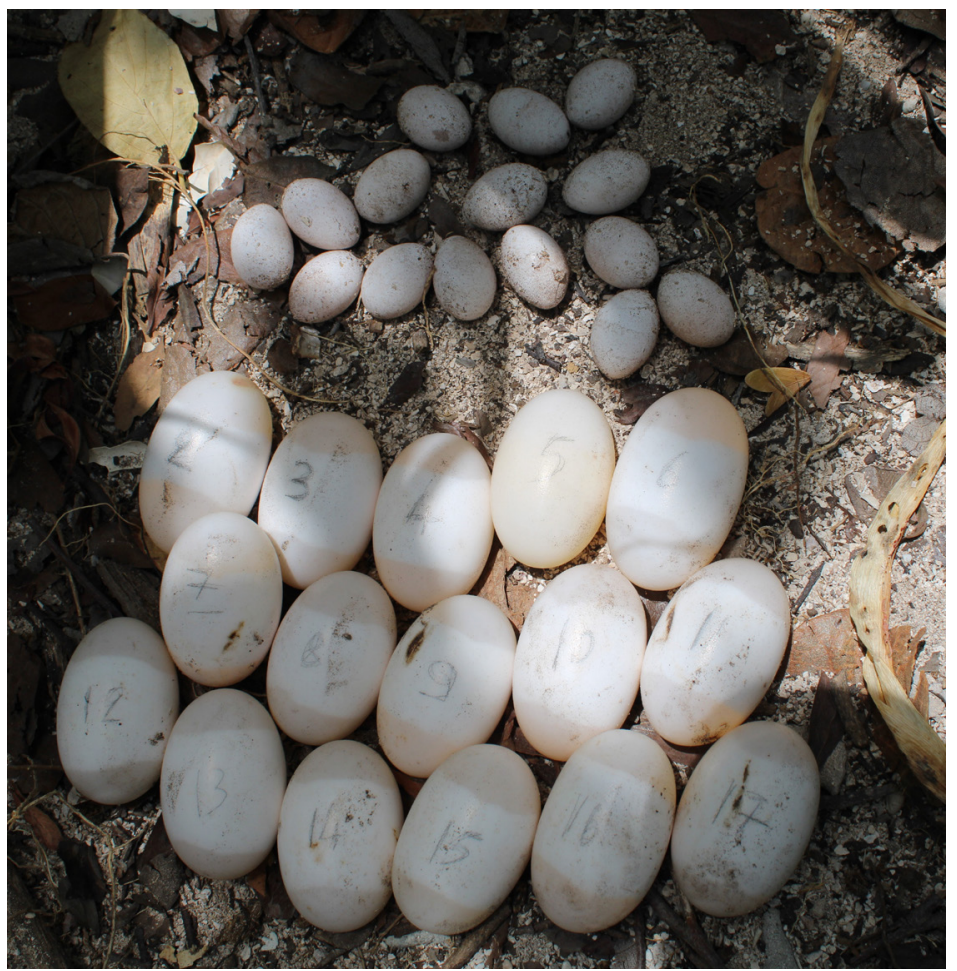

Figure 1. American crocodile and iguana clutches found together in the same cavity at Cayo Centro, Banco Chinchorro Atoll, Mexico. Photo by Pierre Charruau.

to nest communally with crocodilians, including C. acutus (Dugan et al. 1981, Bock \& Rand 1989, Platt et al. 2010, 2021), and we already observed that this species uses the same nesting areas as C. acutus at Banco Chinchorro, sometimes digging up crocodile eggs as observed in Panama (Bock \& Rand 1989, Charruau \& Hénaut 2012). We have also observed Ctenosaura similis on nests of Crocodylus acutus in Banco Chinchorro (Charruau \& Hénaut 2012). However, out of 204 crocodile nests found to date on Cayo Centro since 2006, this is the first time (0.5\%) that we found an iguana clutch in the same cavity as a crocodile clutch. Although I. iguana is the most likely species that deposited the eggs along with those of the crocodile, we cannot exclude the possibility that Ctenosaura similis is as well. Future research on reproductive ecology of the green and black iguanas at Banco Chinchorro should be conducted to provide elements to differentiate the clutches of these species.

Other species of reptiles, birds, mammals, and arthropods have been observed at crocodile nesting sites at Banco Chinchorro (Charruau \& Hénaut 2012, Gagnon et al. 2018). However, none of them have been observed nesting in crocodile nests. In addition, black rats (Rattus rattus) and feral cats (Felis catus) have been eradicated and are no longer present on the atoll (Charruau 2021). It is likely that birds use these sites to sunbathe, forage for nest building material, forage for food, or scavenge crocodile eggs (Charruau \& Hénaut 2012, Platt et al. 2014, P. Charruau, personal observation). Blue land crabs (Cardisoma guanhumi) and Caribbean hermit crabs (Coenobita clypeatus) have been observed passing on crocodile nests, and on one occasion we observed a red crab (Gecarcinus lateralis) digging up a crocodile egg from a nest as it built its tunnel (Charruau et al. 2012, P. Charruau, personal observation). The other reptiles observed at crocodile nests the Cuban blue anones (Anolis allisoni), Cuban brown anoles (Anolis sagrei), and Maslin's whiptails (Aspidoscelis maslini), only appear to pass on the nest without showing other types of interaction (Charruau \& Hénaut 2012). Among other animals observed at crocodile nesting sites was one centipede (Scolopendra viridis) collected from a crocodile nest's substrate (Gagnon et al. 2018).

Multiple hypotheses have been proposed to explain intra- and interspecific communal egg-laying in reptiles (Doody et al. 2009, Escobedo-Galván et al. 2019). One possible explanation for the occurrence of this life trait between iguanas and crocodiles is that iguana clutches receive protection from the female crocodile that aggres- 


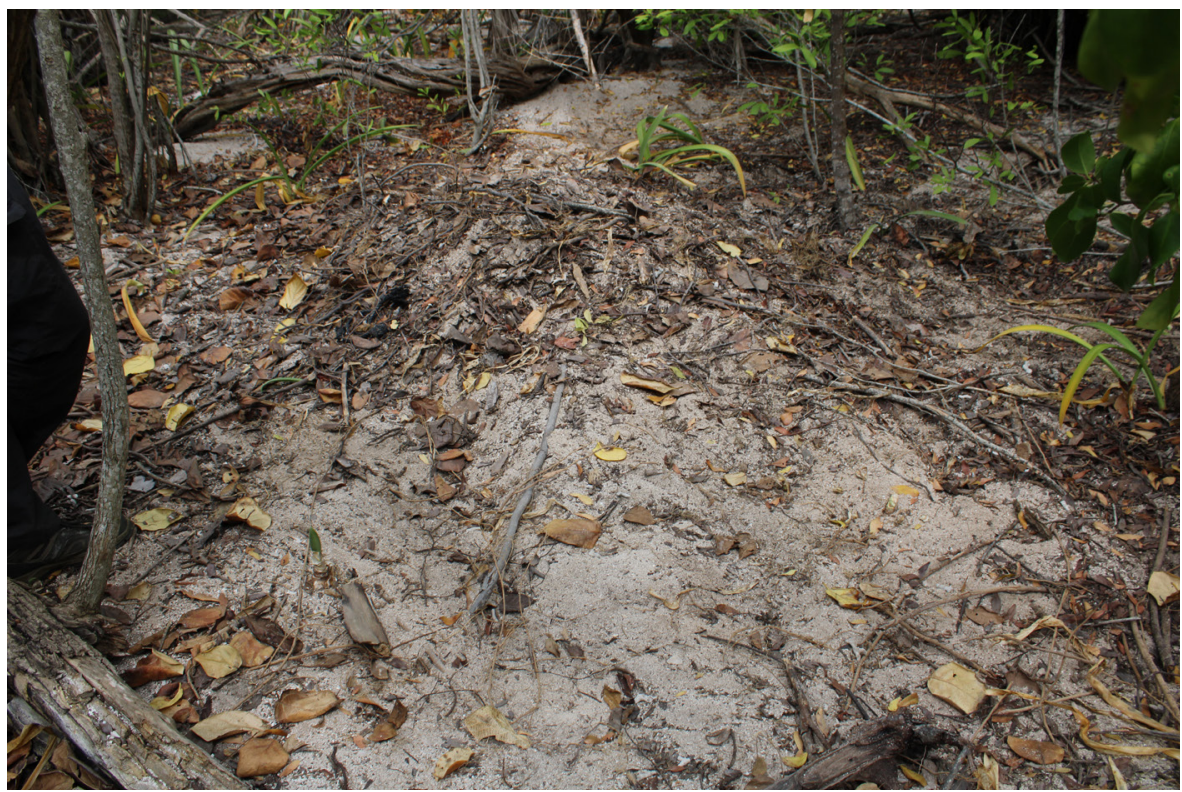

Figure 2. The American crocodile mound nest where interspecific communal egg-laying between crocodile and iguana was observed. Photo by Pierre Charruau.

sively guards her nest, improving the survival of the iguana clutch, although this may also cause the death of some female iguanas and the loss of clutches, predated and dug up by crocodiles respectively (Bock \& Rand 1989, Dugan et al. 1981, Platt et al. 2010, 2021, Escobedo-Galván et al. 2019). However, there are no predators of crocodile clutches at Cayo Centro, and the protective behavior of female crocodiles seems to be reduced in the reserve compared to other sites with a higher presence of predators (Charruau \& Hénaut 2012). Thus, this would not support this hypothesis. In addition, the iguana's clutch was below that of the crocodile, suggesting that the iguana laid its eggs first without knowing if a crocodile would nest in this location.

In our case the reduced nesting areas available on the island for iguanas and crocodiles are probably the main reason for the occurrence of interspecific communal egg-laying. Crocodylus acutus, Iguana iguana, and Ctenosaura similis are known to nest communally or gregariously with conspecifics sometimes (Bock \& Rand 1989, Lee 2000, Alonso-Tabet et al. 2014), show similar requirements for nest site selection, and nest at the same time of the year at Banco Chinchorro. All of them select elevated and open sandy areas that avoid flooding and allow them to receive a good amount of solar radiation, providing adequate conditions for optimal embryo development (Bock \& Rand 1989, Charruau et al. 2010, Campos \& Desbiez 2013, Lee 2000). These areas are limited in Cayo Centro and this may lead to interspecific competition for these sites as has been observed in Panama (Dugan et al. 1981, Bock \& Rand 1989, Charruau et al. 2022).

\section{Acknowledgements}

We thank S.G. Platt and A.H. Escobedo-Galván for their comments to improve the manuscript. We also thank the staff of the Banco Chinchorro Biosphere Reserve for their valuable logistical assistance in the field. The study was conducted under the authorization of the Secretaría de Medio Ambiente y Recursos Naturales (SEMARNAT) of Mexico under permit number SGPA/DGVS/07900/20.

\section{References}

Alfonso YU, Charruau P, Fajardo G, and Estrada AR (2012) Interspecific communal oviposition and reproduction of three lizard species in Southeastern Cuba. Herpetology Notes, 5, 73-77. Article

Alonso-Tabet M, Ramos R, Rodriguez-Soberón R, Thorbjarnarson JB, Belliure J, Berovides V (2014) Los Crocodylia de Cuba (Publicaciones de la Universidad de Alicante, Alicante, España). 
Alvarado J, Ibarra L, Suazo I, Rodríguez G, and Zamora R (1995) Reproductive characteristics of a Green iguana (Iguana iguana) population of the west coast of Mexico. The Southwestern Naturalist, 40, 234-237. Article

Avery ML, Tillman EA, Spurfeld C, Engeman RM, Maiejewski KP, Brown JD, and Fetzer EA (2014) Invasive black spinytailed iguanas (Ctenosaura similis) on Gasparilla Island, Florida, USA. Integrative Zoology, 9, 590-597. Article

Bock BC, and Rand AS (1989) Factors influencing nesting synchrony and hatching success at a green iguana nesting aggregation in Panama. Copeia, 1989, 978-986. Article

Campos Z, and Desbiez AL (2013) Structure of size and reproduction of green iguanas (Iguana iguana) in the Brazilian Pantanal. IRCF Reptiles \& Amphibians Conservation and Natural History, 20, 53-56. Article

Charruau P (2012) Microclimate of American crocodile nests in Banco Chinchorro Biosphere Reserve, Mexico: Effect on incubation length, embryos survival and hatchlings sex. Journal of Thermal Biology, 37, 6-14. Article

Charruau P (2021) The mastofauna of Banco Chinchorro Atoll, Mexico. Caribbean Journal of Science, 51, 213-222. Article

Charruau P, Cedeño-Vázquez JR, and Calmé S (2005) Status and conservation of the American crocodile (Crocodylus acutus) in Banco Chinchorro Biosphere Reserve, Quintana Roo, Mexico. Herpetological Review, 36, 390-395.

Charruau P, Thorbjarnarson JB, and Hénaut Y (2010) Tropical cyclones and reproductive ecology of Crocodylus acutus Cuvier, 1807 (Reptilia: Crocodilia: Crocodylidae) on a Caribbean atoll in Mexico. Journal of Natural History, 44, 741-761. Article

Charruau P, and Hénaut Y (2012) Nest attendance and hatchling care in wild American crocodiles (Crocodylus acutus) in Quintana Roo, Mexico. Animal Biology, 62, 29-51. Article

Charruau P, Hénaut Y, and Álvarez-Legorreta T (2013) Organochlorine pesticides in nest substratum and infertile eggs of American crocodiles (Reptilia, Crocodylidae) in a Mexican Caribbean atoll. Caribbean Journal of Science, 47, 1-12. Article

Charruau P, Díaz de la Vega Pérez AH, and Méndez de la Cruz FR (2015) Reptiles of Banco Chinchorro: Updated list, life history data, and conservation. The Southwestern Naturalist, 60, 299-312. Article

Charruau P, Pérez-Juárez JG, Medina M, Méndez de la Cruz FR, and Pérez-Flores J (2020) Bacterial flora of wild black (Ctenosaura similis Gray, 1831) and Green (Iguana iguana Linnaeus, 1758) iguanas from a Mexican Caribbean atoll. Herpetology Notes, 13, 369-376. Article

Charruau P, Ichbia D, Gónzalez-Desales GA, and Platt SG (2022) Reproductive dynamics of an isolated population of American crocodiles (Crocodylus acutus) based on long-term monitoring data. Journal of Herpetology (in press).

Doody JS, Freedberg S, and Keogh JS (2009) Communal egg-laying in reptiles and amphibians: evolutionary patterns and hypotheses. The Quarterly Review of Biology, 84, 229-252. Article

Dugan BA, Rand AS, Burghardt GM, and Bock BC (1981). Interactions between Nesting Crocodiles and Iguanas. Journal of Herpetology, 15, 409-414. Article

Escobedo-Galván AH, Elsey RM, Mc Cann F, Cupul-Magaña FG, and Lopez-Luna MA (2019) Putting eggs in one big basket: communal egg-laying between long-lived reptiles. North-Western Journal of Zoology, 15, 96-100. Article

Espinoza RE, and Lobo F (1996) Possible communal nesting in two species of Liolaemus lizards (Iguania: Tropiduridae) from Northern Argentina. Herpetological Natural History, 4, 65-68.

Fitch HS, and Henderson RW (1978) Ecology and exploitation of Ctenosaura similis. The University of Kansas Science Bulletin, 51, 483-500.

Gagnon R, Dupuis F, and Charruau P (2018) Record of Scolopendra viridis Say, 1821 (Chilopoda: Scolopendromorpha: Scolopendridae) from Banco Chinchorro Biosphere Reserve, Quintana Roo, Mexico. Dugesiana, 25, 33-35. Article 
Lee JC (2000) A field guide to the Amphibians and reptiles of the Maya world, the lowlands of Mexico, Northern Guatemala, and Belize (Cornell University Press, Ithaca, New York).

Muñoz EM, Ortega AM, Bock BC, and Páez VP (2003) Demografía y ecología de anidación de la iguana verde, Iguana iguana (Squamata: Iguanidae), en dos poblaciones explotadas en la depresión Momposina, Colombia. Revista de Biología Tropical, 51, 229-240. Article

Platt SG, Rainwater TR, Thorbjarnarson JB, and Hekkala ER (2010) Iguana iguana (Green Iguana). Nesting. Herpetological Review, 41, 493-494.

Platt SG, Charruau P, and Rainwater T (2014) Scavenging of crocodile eggs by vultures (Cathartes aura and Coragyps atratus). Bulletin of the Texas Ornithological Society, 47, 37-40.

Platt SG, Rainwater TR, and McMurry ST (2021) Fauna associated with the nests of Crocodylus moreletii and Crocodylus moreletii $\times$ acutus in Belize. Journal of Natural History, 55, 133-149. Article

van Marken Lichtenbelt WD, and Albers KB (1993) Reproductive adaptations of the green iguana on a semiarid island. Copeia, 1993, 790-798. Article 